\title{
Afetos ao trabalho - notas sobre a sedução da subjetividade em uma empresa brasileira de moda*
}

\author{
Nicolas Wasser**
}

\begin{abstract}
Resumo
Afetos veiculam uma intensidade de marcadores sociais e de subjetividade. Com isso, tornam-se altamente lucrativos para as indústrias que se alimentam das capacidades do corpo. Recorrendo a notas etnográficas sobre a Visibly Hot, uma empresa brasileira de óculos, este artigo foca as seguintes questões: com quais instrumentos essa marca regula desejos e aspirações para promover seus produtos e cativar seus funcionários? E, como os próprios funcionários participam e manipulam esse processo? Por um lado, o slogan de "ser diferente" promove uma pluralização de subjetividades, efetuando um controle avançado de identidades sexuais e raciais. Por outro lado, os vendedores acabam aprendendo suas próprias técnicas afetivas (identificação com a marca, incitação sexual) que, uma vez postas em movimento, simultaneamente aumentam e perturbam o fluxo normatizado pelas vendas.
\end{abstract}

Palavras-chave: Afetos, Subjetividade, Diversity Management, Sexualidade, Trabalho.

\footnotetext{
Recebido para publicação em 16 de julho de 2014, aceito em 10 de agosto de 2015.

** Doutorando pelo Programa de Pós-Graduação em Sociologia e Antropologia Núcleo de Estudos de Sexualidade e Gênero, Universidade Federal do Rio de Janeiro, Rio de Janeiro, Brasil, e Associado ao Grupo de Pós-Graduandos em Estudos de Gênero, Universität Basel, Basileia, Suíça. nicolas.wasser@gmail.com 
Affects at Work - Notes on the Seduction of Subjectivity in a Brazilian Fashion Enterprise

\begin{abstract}
Affects carry an intensity of social markers and subjectivity: lately, they have become highly profitable for industries that rely on the capitalization of bodily capacities. Based on ethnographic insight about Visibly Hot, a Brazilian retailer of sunglasses, the article focuses on the following questions: what are the instruments used by the enterprise that generate desire and aspirations that are being aimed at promoting their products and captivating their employees? Further, how do the proper employees participate and manipulate this process? On the one hand, the slogan "be different" promotes a multiplication of subjectivities, thus generating an advanced control of sexual and racial identities. On the other hand, the salesclerks develop their own affective techniques (identification with the brand, sexual stimulation) that once set in motion both enhance and trouble the channeled flow of sales.
\end{abstract}

Key Words: Affects, Subjectivity, Diversity Management, Sexuality, Labor. 


\section{Introdução}

Ser diferente - esse é o lema e a receita de sucesso da Visibly Hot $^{1}$, uma das mais exitosas varejistas brasileiras de moda dos últimos anos. Com o fim de vender seus óculos e acessórios, essa empresa está arquitetando uma marca que estimula os desejos por uma pluralidade de identidades - alternativas, sexuais, raciais e de juventude. $\mathrm{O}$ modelo de marketing empregado não seria tão novo, se não houvesse um vasto entusiasmo por parte dos seus jovens funcionários. Carol, uma vendedora da Visibly Hot, relata que se sentia desfavorecida por ser lésbica, razão pela qual optou por trabalhar na empresa. Segundo ela, a marca lhe possibilitava "ser assim como ela é". Por isso, a tatuagem com o símbolo da Visibly Hot que Carol fez no próprio braço funcionaria como a prova da relação íntima mantida com a marca: "É que eu amo a marca, não vou me arrepender disso. É Visibly Hot na minha veia".

Como efeito da flexibilização entre trabalho e vida na era do pós-fordismo, observa-se uma infiltração mútua entre as articulações político-sexuais e os interesses do comércio. No exemplo do mercado brasileiro voltado para gays, o espírito do negócio não se limita a promover identidades já consolidadas, mas "contribui para a produção mesma de sujeitos, categorias e estilos" (França, 2012:19). Essa constatação também se torna evidente no exemplo de trajetórias de jovens homossexuais negros do subúrbio carioca. Segundo o estudo de Moutinho (2006), o circuito GLS lhes confere um capital cultural específico, baseado na sua cor negra, e agente especialmente ao encontro com homens brancos estrangeiros. Nesse contexto, são as circulações de afetos e prazeres sexuais que produzem identidades de raça:

1 Nome alterado. Devido aos direitos de autor da empresa, assim como à garantia que não conterá qualquer informação que poderá ser usada para identificar um indivíduo, todas as evidências foram anonimizadas. Consequentemente, as fontes de Youtube e Facebook consultadas não poderão ser indicadas. 
são emoções ${ }^{2}$, por usar as palavras de Ahmed (2004), que criam uma sensação de intensidade, relacionada tanto ao estabelecimento de um "nós" como à delimitação de "outros". De acordo com a autora, as emoções e os afetos "desempenham um papel crucial no surgimento de corpos individuais e coletivos" (Ahmed, 2004:25, tradução minha).

Este artigo discute o envolvimento mútuo entre marketing, sexualidade e raça/cor pelo papel que os sentimentos desempenham no trabalho de jovens vendedoras $e$ vendedores. Como práticas culturais que mediam pertencimento (Schmitz e Ahmed, 2014:101), as emoções tornaram-se instrumentos altamente explorados pelo mercado, pela propaganda de produtos e pelos regimes do trabalho afetivo. Tal fenômeno será abordado na indústria de moda brasileira e, mais especificamente, recorre-se ao material etnográfico sobre a Visibly Hot. Essa empresa de óculos e acessórios é o foco da minha tese de doutorado sobre a transformação da subjetividade e do trabalho, relacionada à incitação e à capitalização neoliberal das diferenças e dos desejos sexuais. A mesma companhia é considerada aqui como exemplo da arquitetura afetiva que infiltra diferentes canais de articulação identitária: estratégias de marketing, incluindo propagandas, eventos internos e a presença nas mídias e redes sociais. Além desse material midiático-ostentativo, o estudo se refere a entrevistas semiestruturadas feitas com 16 jovens funcionários localizados no Rio de Janeiro. Nas conversas, focalizou-se a inserção dos jovens no trabalho, seu dia a dia na venda de

2 Sigo a argumentação de Ahmed (2004; 2014) contra uma separação analítica clara entre afetos, emoções e sentimentos. Diferente de autores, como Massumi (2002), que sugerem que os afetos descreveriam as sensações "imediatas" $e$ prediscursivas, em oposição às emoções como os sentimentos "conscientes" $e$ sócio-históricos, a teórica feminista escolhe o termo emoção como a noção que engloba todos os movimentos sensíveis. Esses movimentos são sempre historica $e$ culturalmente situados, se bem que não somente circulem em um sujeito delimitado. As emoções como movimentos podem incluir e direcionar também objetos ou situações. Com isso, são mediadores que fazem surgir corpos individuais e coletivos, materializando a dicotomia racializada entre "nós" e os "outros" (Ahmed, 2004). 
produtos e, em específico, sua compreensão singular de identidades (sexuais, raciais e de juventude) afetivamente relacionadas à marca da empresa.

Tanto os debates recentes em torno do trabalho imaterial $e$ afetivo (Hardt e Negri, 2000) como os aprofundamentos dos estudos de gênero e sexualidade apontaram para a centralidade dos afetos para a manutenção ou manipulação das relações de poder. Como indica Piscitelli (2007:28), as trabalhadoras transnacionais de sexo se encontram em negociações conflituosas: elas mobilizam $e$ adaptam as qualidades afetivas supostamente relacionadas à nacionalidade. A ativação de temperamento, sensualidade, alegria $e$ afetuosidade aparecem, assim, como garantia de seu sucesso profissional. A necessidade dos afetos está avançando em diferentes esferas dos vínculos empregatícios (Vargas, 2009), sendo esse um processo entrelaçado com a instigação dos prazeres pelo mercado (McClintock, 2010). No caso brasileiro, o papel das emoções e sentimentos vem sendo discutido com foco no trabalho de cuidado (Hirata e Guimarães, 2012), no trabalho no setor de serviços (Soares, 2002) assim como no trabalho doméstico (Brites, 2007). Partindo dessas reflexões, pretendo chamar a atenção para três movimentos interligados: 1) Varejistas como a Visibly Hot precisam incentivar os fluxos afetivos: o motor lucrativo está na estimulação das aspirações e sonhos identitários dos seus funcionários e consumidores; 2) o trabalho requisitado aos funcionários não se restringe a vender um produto, produzindo igualmente sujeitos sexualmente corporificados e afetivos; 3) os efeitos dessa produção permanecem ambíguos: os funcionários alimentam $e$ ocasionalmente perturbam os processos normativos voltados para a venda.

Na primeira parte, discutirei o papel da identidade no dia a dia dos funcionários da Visibly Hot. De acordo com a presente leitura, esses jovens estão articulando aspirações - assim como as de "amar" a marca ou "poder ser como eles são" - que estão relacionadas com suas próprias experiências de habitar diferenças socialmente desvalorizadas, tais como baseadas em homossexualidade ou em cor/raça negra. Como efeito das 
mudanças ocorridas no âmbito do trabalho, os funcionários estão desenvolvendo uma conduta afetivo-corporal, um esforço em articular aquelas identidades anteriormente desvalorizadas. Em seguida, a segunda parte visa compreender esses esforços por parte dos funcionários no marco das técnicas afetivas diretamente induzidas pela empresa. A pluralidade de identificações propagandeadas pela Visibly Hot serve como base tanto de lucro como de controle dos funcionários. Finalmente, a terceira parte pretende acentuar as ambivalências das técnicas afetivas. Os vendedores, principalmente, mobilizam fantasias sexuais na interação com os clientes que aumentam as vendas, mas também as põem em perigo. Em alguns casos, a sensualidade instigada pela marca volta-se contra a empresa e seus lemas.

\section{Trabalho afetivo é trabalho na identidade}

A Visibly Hot vende seus acessórios e óculos principalmente em shopping centers. Seus vendedores trabalham em quiosques que estão localizados nos corredores. Diferentemente do que ocorre nas lojas integradas, o modo de apresentação corporal é peculiarmente relevante porque no quiosque não há nenhuma possibilidade de não ser visto pelos passantes. A interação com os clientes, bem como qualquer movimento corporal no tempo que transcorre entre as vendas, está exposta aos olhares públicos. Com isso, os vendedores elaboram um próprio jeito que responde às exigências relacionadas tanto a essa publicidade quanto à necessidade primária de vender um produto. De maneira geral, o cuidado com a aparência e o tratamento emocionalmente adequado dos clientes são os fatores mais destacados pelos funcionários. Eles mesmos recomendam não só "tratar o cliente como se fosse um amigo", mas também "identificar-se com a marca". Como disse Bruna, que trabalha como vendedora responsável na Zona Norte do Rio de Janeiro, "você tem que acreditar no que você vende".

Para os vendedores da Visibly Hot, jovens entre 18 e 23 anos de idade, parece natural recorrer a essa identificação com os 
produtos da marca em termos de uma modelação do seu corpo. A maioria das meninas e meninos acompanhados na pesquisa costuma exibir tatuagens, piercings e cortes de cabelo que fazem alusão a um ou a vários estilos ${ }^{3}$ urbanos. Bruna, por exemplo, enfatiza sua própria trajetória no movimento estudantil, na militância LGBT e no meio artístico da produção fotográfica $e$, durante sua entrevista de emprego, destacou a tatuagem que possui. O vendedor Fernando, por sua vez, gosta da estética da música afro-americana dos Estados Unidos, como disse, a de "bem brooklyn" que, segundo ele, expressa através do seu cabelo $e$ do uso de acessórios. Porém, não são todos os membros das equipes de vendedores que se identificam explicitamente com um estilo específico. Alguns se autoclassificam como adeptos de uma moda "mais básica". Mas, como relatou a vendedora Marina, o fato de não apresentar um estilo chamativo às vezes a leva a questionar se ela "realmente se encaixa" na marca. Porque, apesar de multiplicar os tipos ideais, a Visibly Hot dá preferência àquele jovem que ativamente cria e estiliza seu corpo. "Ser diferente", o slogan da marca, ilustra muito bem esse fenômeno. Na verdade, o esforço de elaborar uma individualidade através do estilofaz parte do compromisso que os funcionários mantêm com a Visibly Hot.

Os exemplos desses investimentos individuais podem oferecer uma maior compreensão de como uma regra ou lógica de mercado se torna efetiva com base em processos de identidade. Pois, a ética de trabalho encontrada na Visibly Hot se constitui pela enunciação dos vendedores de uma suposta verdade sobre si mesmo. Ainda que nem todos se "encaixem" no imperativo do "ser diferente", eles buscam uma ponte individual para essa mesma promessa. Identidades, na definição de Hall (1996), são pontos de "sutura" entre discursos que nós atribuímos

3 Eu sigo a noção de Facchini (2011), segundo a qual estilo não só engloba uma forma espetacular de se apresentar visualmente, mas também opera nas relações de poder por inscrever diferenças (Facchini, 2011:137). Através do exemplo das minas de rock, a autora ainda acrescenta que trata-se de um processo de subjetivação, no qual é crucial o papel da sexualidade. 
a certas posições sociais e investimentos que os sujeitos efetuam nessas posições. Os sentimentos, as práticas e as formas de pensar dos indivíduos devem ser compreendidos como "articulações", isto é, processos em que indivíduos

\begin{abstract}
modelam, estilizam, produzem e "performam" essas posições, e por que eles nunca o fazem completamente, de uma vez por todas, e alguns nunca o fazem mesmo ou estão em um constante processo agonístico, lutando, resistindo, negociando e acomodando as regras normativas ou regulativas pelas quais eles se confrontam e se regulam a si mesmos (Hall, 1996:14, tradução minha).
\end{abstract}

Além do aspecto processual e inacabado das articulações identitárias, vale lembrar que elas compõem regimes de identidade que, muitas vezes, implicam em uma hierarquização dos e pelos marcadores de diferença. De acordo com Brah (2006), a questão-chave diz respeito a quem define diferença e de que maneira essa diferença define o "outro" (2006:359), pois essas definições poderiam ser usadas para políticas tanto inclusivas como (essencialmente) exclusivas.

Por conseguinte, posicionar e situar-se nessas relações de diferença são processos que pedem um esforço considerável pelos indivíduos. $\mathrm{O}$ exemplo das trabalhadoras de sexo brasileiras que trabalham em países europeus (Piscitelli, 2007; 2009) ilustra muito bem esse caráter não só estratégico, mas também interseccional que os marcadores de diferença desdobram sob um dado regime empregatício. Ao investir na construção $e$ na venda de feminilidades eróticas, essas trabalhadoras veiculam identificações de nacionalidade, já que na competição por clientes, "a brasileira" é valorizada por ter uma sensualidade supostamente "natural" (Piscitelli, 2007:28). No contexto do mercado transnacional do sexo, esse estereótipo é visto em termos de uma competência, relacionada a estilos corporais $e$ afetivos que instigam a sexualização e racialização da nacionalidade. Isso faz com que, por exemplo, as trabalhadoras nigerianas sejam rechaçadas por 
serem nigerianas, e não necessariamente por serem negras. Ao mesmo tempo, as trabalhadoras brasileiras podem se aproveitar das imagens exóticas da mulata carinhosa (Piscitelli, 2007:26). A diretriz da competência preenche os marcadores sociais de diferença com sentido hierarquizante: aquelas mulheres com estilos corporais menos favorecidos vão precisar de mais investimento e esforço competitivo para que sejam desejadas pelos clientes.

Voltando ao exemplo da Visibly Hot, também se observam desejos por competência de estilo corporal que, no caso, diluemse com a vontade por pertencimento social. $\mathrm{O}$ caso da vendedora Carol mostra que seus investimentos em produzir um corpo "diferente" estão refletindo suas aspirações mais amplas de viver e trabalhar sem mal-estar. Ela tinha 17 anos e já gostava muito da marca porque, em suas palavras, tinha visto "uma galera mais alternativa". Já costumava comprar os produtos e fez amizade com as pessoas que trabalhavam na loja. Com 18 anos, pensava que tinha que trabalhar e que a Visibly Hot oferecia a melhor opção. "Então, falei: cara, quero trabalhar nessa loja. Eles vão me aceitar do jeito como eu sou, com o meu estilo, com a minha opção sexual". Carol é uma das funcionárias mais leais ao espírito da marca. Além de se entusiasmar com as pessoas e estilos presentes, ela aponta para o seu antebraço, adornado por uma tatuagem do símbolo da empresa: "Visibly Hot na veia. Mesmo saindo da empresa, não vou me arrepender disso aqui; que eu amo a marca mesmo, é a minha cara."

A tatuagem da Carol é emblemática para a questão da identidade produzida no âmbito da Visibly Hot. Por um lado, reconhecemos uma forma sofisticada de modelar o corpo conforme os estilos que circulam no mundo da empresa. Por outro lado, tatuagem não é simplesmente uma espécie de joia ou acessório que se tira ao final do dia. $\mathrm{O}$ que aprendemos com a fala de Carol é que a (im)possibilidade de arrependimento ainda intensifica a identificação com a empresa. A importância da Visibly Hot está, segundo ela, no amor, ou seja, na relação afetiva e íntima que mantém com a marca. Para dar ênfase a essa 
afetividade, Carol costuma usar as redes sociais online. Como os seus colegas de trabalho, ela tira séries de fotos que a retratam no quiosque e em treinamentos da empresa. Em seguida, posta as fotos no Facebook, divulgando uma imagem dela como uma pessoa intimamente integrada à sua equipe e com um laço imediato com o fundador da Visibly Hot. Nos próprios comentários, ela destaca a beleza e o carinho dos seus colegas bem como sua admiração pelo "pai" da marca. Na mesma linha, Bruna também publicou uma foto no seu site, onde ela pergunta: "Como não amar esse homem? O homem que criou o universo paralelo onde eu vivo hoje."

Por fim, as articulações de identidades pelos jovens funcionários aparecem à luz das mudanças ocorridas na gestão do trabalho. Ainda na era do fordismo, a base do sistema de produção em massa estava na separação entre a fábrica e o lazer, ou seja, entre o trabalho e a vida. Como mostraram os teóricos do pós-operaísmo (ver Hardt e Negri, 2000), o desenvolvimento tecnológico e a intensificação da comunicação decompuseram essas esferas. Para os vendedores como Carol, já não parece preciso distinguir suas aspirações privadas das públicas. As sensações de estar ameaçada por homofobia ou de autoestima apoiadas em imagens afetivas de si estão sendo articuladas, de fato, no âmbito comercial da Visibly Hot. Lá existe um interesse em patrocinar a expressividade subjetiva, pois é essa que promete a criação de lucro. Esse incentivo está trazendo novas exigências para o dia a dia dos vendedores. Além de ter que vender um produto-objeto, o funcionário está sendo "intimado a produzir-se como um sujeito" (Lorenz e Kuster, 2007:19), como um corpo estilizado, incluindo o manejo dos seus afetos.

De acordo com a crítica feminista aos teóricos do pósoperaísmo (ver McRobbie, 2010), esse modo de trabalho não é bem descrito pela sigla "trabalho imaterial". Com base nessa crítica, algumas autoras feministas e queer optam pela noção de trabalhar sexualmente (sexuell arbeiten, no caso de Lorenz e Kuster, 2007), trabalho sexual (sexual work, no caso de Adkins, 1995) ou trabalho farmacopornográfico (Preciado, 2008) a fim de dar mais 
visibilidade ao papel de gênero e da sexualidade como requisito $e$ efeito do trabalho capitalista. Igualmente insistindo no caráter subjetivante dessa atividade, eu prefiro, aqui, o termo genérico trabalho afetivo, porque continua sendo mais aberto para, além da subjetivação sexual, abranger outros eixos poderosos de diferença e desigualdade, tais como a raça ou a classe social.

No caso do vendedor Fernando, o processo de subjetivação se realiza com respeito à busca identitária relacionada tanto à black music quanto a ser jovem e gay. Ele costuma não só frequentar as boates que lhe oferecem esse estilo, mas também dar forma corporal a essa modalidade de si. Seu cabelo black e seus acessórios do mundo pop abrem a oportunidade de ser reconhecido, como tal, nos contextos preferidos por ele. Nesse sentido, a Visibly Hot é apenas um dos espaços onde isso pode acontecer, porém, com a especificidade de que os estilos mobilizados ali são valorizados enquanto capital cultural imediato. A própria apresentação de um corpo reconhecidamente estilizado - jovem gay, jovem negro, jovem alternativo - contribui à venda eficaz de um produto, quando não a garante.

Esse corpo afetivo é uma produção que transcende os limites anteriores do espaço-tempo, já que sua produtividade não se restringe à esfera do trabalho. $\mathrm{O}$ que se observou com o corpo tatuado da Carol é que ele já vem parcialmente produzido antes de ela entrar, como vendedora, na Visibly Hot. A forma, então, pela qual os jovens em destaque estão manejando a diferenciação de corpos tem referências sociais mais amplas. São referências que não se deixam simplificar em termos de incorporação ou captura capitalista induzida pela empresa. De acordo com Beatriz Preciado (2011), é preciso pensar melhor a atuação do dispositivo farmacopornográfico que estaria reinando nas sociedades pósfordistas: formas de controle, tanto molecular quanto audiovisual, que visam estimular os sujeitos de modo que mantenham a capacidade de tornar-se capital pleno. A confluência dessa produção subjetiva estaria na excitação da potentia gaudendi, uma capacidade orgasmática inerente aos corpos. Consequentemente, os chamamentos contemporâneos pareceriam 
um laboratório "no qual o controle dos fluxos e dos afetos se realiza através da forma pop da excitação-frustração" (Preciado, 2011:44, tradução minha).

A tensão afetiva que Preciado descreve como efeito do controle farmacopornográfico está acompanhando as sensações subjetivas dos jovens vendedores. Fernando e Carol foram literalmente excitados pela atratividade que irradia da Visibly Hot. Ao mesmo tempo, eles experimentaram frustração no processo do recrutamento. Os dois não conseguiram ser contratados na primeira entrevista.

Eu fui reprovado em três entrevistas, eu acho. [...] Então, eles querem escolher aquela pessoa que fala bem, pessoas que não têm vergonha. [...] Eu sei falar, só que na época, eu era mais reservado. Apesar do meu estilo diferente, eu era mais calmo [Fernando, vendedor da Visibly Hot].

Fernando destaca que, na época das primeiras entrevistas, ele já estava com o "estilo diferente". Contudo, isso não era suficiente para convencer a Visibly Hot de sua qualificação. De acordo com o próprio Fernando, ele ainda não estava com a postura certa: faltava, segundo ele, "personalidade" para uma forma mais aberta e direta na interação com as pessoas. Somente depois descobriu o que era pedido a ele - uma "atitude", como se diz no vocabulário da empresa, que corresponde a uma capacidade de ser convincente e seguro de si.

A Visibly Hot atribui bastante importância ao desenvolvimento dessas técnicas de si por seus funcionários. Orientados, metodologicamente, por treinamentos em grupo, os vendedores têm que aprender esse manejo, propagandeado, aliás, como rótulo da Visibly Hot, pelos exercícios diários do seu emprego. O gênero do trabalho afetivo, no caso, refere-se ao incentivo à produção subjetiva: não simplesmente produz um corpo de sexualidade e raça estilizadas, mas também demarca uma postura específica, ou seja, uma condução individual dos fluxos e afetos desejantes. 


\section{O governo da diferença}

É importante frisar que a categoria de "atitude" continua estreitamente entrelaçada com a propaganda pela gestão da diversidade (diversity management). ${ }^{4}$ Quando Andrea, gerente de uma loja Visibly Hot no Rio de Janeiro, comenta os requisitos para o emprego como vendedor, ela começa falando que o candidato deveria ter o estilo da marca, o do "diferente". "Tem que se identificar um pouco, querendo ou não". Mas também ressalta que ela exige "convicção" na entrevista de recrutamento, uma certeza da pessoa "do que ela quer". É essa dupla - a tendência para um estilo corporal transgressivo com uma personalidade firme no sentido de resoluto - que, aparentemente, guia a seleção dos candidatos ideais. Como a supervisora Ana fala claramente: "A gente define que a marca trabalha com pessoas diferentes".

Ora, de onde advém essa preocupação com as diferenças e as identidades alternativas? De acordo com a própria narrativa da empresa, a Visibly Hot foi criada por Diogo, músico de rock que tinha se apaixonado pelos Estados Unidos e, sobretudo, pela subcultura lá vigente. Sua ideia inicial de vender óculos nasceu em um ambiente de artistas e gente abastada de Los Angeles que, segundo ele, "à noite ou em uma mudança de humor, transformavam-se em tatuados, mutantes, roqueiros, clubbers". A fascinação por esses estilos levou Diogo a querer introduzi-los no Brasil. Em São Paulo, estabeleceu-se com um stand de óculos no Mercado Mundo Mix, um espaço que reunia uma geração jovem de estilistas e artistas. Historicamente situada, essa feira de moda se inseria nos processos de segmentação do mercado nos anos 90 . Era, entre outros, o momento em que se consolidou o mercado GLS (França, 2010:57), incluindo um conjunto de produtos, revistas

4 Refiro-me aqui a um conceito vigente nos departamentos de recursos humanos de empresas privadas $e$ instituições estatais, definido por um instrumento de gestão que mobiliza uma compreensão própria do termo diversidade, vinculada ao lucro econômico $e$ inconfundível com um uso mais comum na área de políticas públicas e nos movimentos sociais relacionadas à promoção da diversidade sexual, de gênero ou de raça. 
e boates sob a sigla de Gays, Lésbicas e Simpatizantes. Como França mostrou em seu estudo aprofundado das práticas de consumo por homossexuais na cidade de São Paulo, essa iniciativa por parte do negócio não só ajudava a "sair do gueto", mas também aumentava, de maneira considerável, o número de consumidores (França, 2010:57).

Depois do estouro no Mundo Mix, Diogo decidiu alargar seu público-alvo. Enquanto na fase inicial, o público era voltado aos "performers, dragqueens, punks" e outras "tribos", a abertura das primeiras lojas em pequenas galerias já usava esses grupos, por assim dizer, para aproveitar o seu efeito exótico. Na descrição de Diogo, um dos primeiros vendedores teria sido bem sucedido justamente por causa do seu "visual assustador", que se expressava através de cabelos brancos e tatuagens nos dedos. Mas há outras figuras que também exemplificam o que o fundador chama de provocação, de seu "oásis de loucura". As propagandas da Visibly Hot têm legendas que estimulam "sensualidade" ou "ousadia" e mostram meninas praticamente nuas se expondo em um ambiente de carros velozes ou florestas coloridas. No entanto, visualiza-se uma pluralidade de identificações. Além de corpos sexuados e estilizados ou de características arrojadas, uma das propagandas mais bem-sucedidas se limitou a ilustrar olhos de animais. Nesse caso, é a analogia entre a riqueza das espécies da fauna e a diversidade dos consumidores que suscita o rótulo da empresa.

Para os profissionais da área do marketing, esse desenvolvimento de identidades representa a base do branding. $\mathrm{O}$ termo (também brand management) equivale, em geral, à gestão de marcas, isto é, ao conjunto das estratégias levantadas pela administração da imagem, do conceito, enfim, do selo chamado marca de uma empresa. Nas últimas décadas, multinacionais, como a Apple, têm intensificado bastante os seus esforços em atribuir uma "vida própria" às marcas. No caso da Apple, a ligação simbólica dos produtos de alta tecnologia a um espírito "mágico" (Isaacson, 2011) rendeu à marca sua grande volta ao mercado. As definições mais recentes de branding destacam que o 
objetivo desse instrumento de marketing está em "criar uma conexão emocional entre produtos, empresas e clientes assim como agentes" (Shamoon e Theseen, 2012:435). Isso nos relembra que existem verdadeiras técnicas de manejo dos laços afetivos que trabalham em função do gerenciamento de uma dada marca.

Foi a socióloga Arlie Hochschild (2003 [1983]) que chamou a atenção para o adensamento dessas técnicas afetivas adotadas pelas empresas multinacionais. Através do exemplo da Delta Airlines, ela mostrou como os sorrisos, a aparência e a conduta simpática das aeromoças criavam um ambiente de "estar em casa" (Hochschild, 2003:7), uma sensação, no cliente, de estar sob conforto e segurança. Para as aeromoças, o trabalho consistia basicamente em aplicar o que elas tinham aprendido nos centros de treinamento: manejar suas emoções conforme o papel de uma feminilidade servil $e$, ainda, convencer aos passageiros de que seu emprego era diversão. Foi devido a essa entrada afetiva que as companhias aéreas conseguiram situar sua marca e amarrar seus clientes.

O então brilho das aeromoças e do status social da viagem aérea pode ter desvanecido. Ainda assim, as observações de Hochschild que datam dos anos 80 já indicam uma tendência que se intensificaria: a gerência começou a assumir o papel de uma espécie de projetista social. Em outras palavras, a marca começou a representar uma arquitetura emocional que abarca não só os consumidores, mas cada vez mais os seus funcionários. Na Visibly Hot, há grandes investimentos para fortalecer a identidade corporativa e propiciar o entrosamento entre os vendedores e os gestores da marca. A cada ano, é produzido certo número de encontros regionais e convenções nacionais. Estas últimas são eventos que contam com vários dias de festa realizados em cruzeiros ou ilhas especificamente alugados. De acordo com um franqueado, tais festas têm uma missão peculiar: "injetar o DNA da Visibly Hot" nas três mil pessoas presentes. Ele sinaliza que só assim os operadores e funcionários mais diversos entenderiam os objetivos e sonhos da marca. 
Certamente, não é nova a crença mobilizada pelo marketing contemporâneo de que uma marca deve parecer mais importante do que o produto em si. Mas, se compararmos o branding da Visibly Hot com o de outras marcas do segmento de moda, particularmente identificamos o quanto a primeira se apropriou das lógicas do diversity management. A multinacional Abercrombie \& Fitch, por exemplo, capturou a atenção midiática por uma provocação corporal uniforme: ela engajou equipes de vendedores masculinos sem camisa. Esses homens desfilavam os seus corpos malhados, tanto na loja como em espetáculos especiais promovidos na 5th avenue de Nova York. A estética da Abercrombie \& Fitch é, porém, simples. São corpos altamente padronizados: quase todos são brancos, musculosos e se dedicam a atividades comumente vistas como masculinas. Em uma das últimas propagandas que retrata um grupo de amigos jogando futebol, um dos meninos até destaca: "Achamos incrível como somos parecidos!".

Ao contrário dessa estratégia baseada na semelhança, a Visibly Hot chama os seus consumidores e funcionários a trabalhar individualmente a pluralidade associada à marca. Diogo explica a fama das suas equipes de vendedores como fruto do seu conceito de evitar a robotização do ambiente, de respeitar a personalidade e o "jeito de ser" de cada um. As pessoas, segundo ele, gerariam uma personalidade no interior do sistema, que, por consequência, se enriqueceria com isso. Esse modelo gerencial faz parte de discursos internacionais que circulam na literatura do management. É o denominado diversity management que iniciou sua difusão com o avanço do neoliberalismo nos anos 80. As empresas aplicadoras partem da ideia de que "a inclusão de minorias historicamente discriminadas melhoraria o ambiente de trabalho" (Saraiva e Irigaray, 2009:338). Na prática gerencial, a contratação de funcionários mulheres, negros e gays estimularia a criatividade do ambiente de trabalho e isso também responderia melhor às demandas diversificadas dos clientes.

É a supervisora Ana quem melhor retrata esse ideário: 


\begin{abstract}
A Visibly Hot é diferente das outras marcas. Porque o vendedor, o funcionário, ele é mais aceito como ele é. Eu acho que isso é uma grande diferença positiva, né? Eu trabalhei em lojas femininas onde a gente não contratava negros; a gente não contratava gente gordinha. Eu já fui desclassificada por lojas femininas por causa da minha altura, porque eu sou baixinha e eu ouvi claramente dizendo que não, que eles estavam procurando um perfil de passarela mesmo. E isso é muito complicado, você saber que tem um profissional de uma característica física, mas para aquela loja, a característica física, ela vem até antes mesmo da capacidade. Na Visibly Hot não. A gente contrata - eu não falo que a gente contrata qualquer pessoa, porque a gente tenta contratar profissionais com excelência. A gente contrata qualquer perfil. A gente não olha se essa pessoa é bonita, feia, gorda, magra, se é gay, qual a opção sexual da pessoa, qual o tipo de vida que ela leva, isso a gente não, não discrimina (Ana, supervisora da Visibly Hot).
\end{abstract}

O cerne da diversidade aqui ambicionada se concentra em deslocar a relação entre normas corpo-identitárias e normas voltadas à "capacidade" lucrativa do funcionário. De acordo com Ana, o grande mérito da Visibly Hot é não "discriminar" as pessoas de baixa estatura ou de cor negra, assim como com estilos de vida que se desviam do marco heterossexual. Ao mesmo tempo, ela deixa claro que não se trata de uma seleção arbitrária do funcionário: o empenho profissional, a "excelência", é o ponto decisivo. E esse, como eu já insinuei anteriormente, está ligado não só a uma conduta de si que facilita as interações de venda, mas também à "atitude", individual e pragmática, voltada à encenação afetiva da própria identidade sexual e/ou racial.

Como parte das minhas entrevistas nas lojas, eu mostrava para os entrevistados quatro fotos que eu tinha tirado da internet. Todas retratavam personagens envolvidas no mundo Visibly Hot: um funcionário da gráfica, uma atriz das propagandas para a convenção no cruzeiro, um grupo de consumidoras comprando óculos na loja e, na última, três meninas posando para a câmera 
em um evento de mídia. Eu escolhi esta última foto, primeiro, porque, diferentemente das outras, retratava jovens negras e, segundo, porque não deixava claro se essas meninas eram consumidoras ou funcionárias da empresa. Aproveitando-me dessa incerteza, pedi para a supervisora Ana avaliar se ela daria emprego para as meninas da foto. Na sua resposta, ela retomou o problema do preconceito racial, presente em outras empresas e na sociedade em geral, a fim de destacar a posição da Visibly Hot.

\begin{abstract}
Elas não seriam aceitas em muitas marcas. Mas a gente não só gosta, mas a gente valoriza. Principalmente porque elas são negras com atitudes que valorizam a raça: o cabelo é bacana. Elas não tentam forçar e fugir desse padrão. Então, de novo, eu vou falar da palavra atitude. Eu acho que elas estariam plenamente classificadas para trabalharem na Visibly Hot (Ana, supervisora da Visibly Hot).
\end{abstract}

Além da sexualidade, a estilização da "raça negra" é aparentemente um dos nós por onde passa o ideário da diversidade na Visibly Hot. $\mathrm{O}$ que se produz por esse procedimento gerencial é um governo que, obviamente, celebra $\mathrm{a}(\mathrm{s})$ diferença(s). Diferenças que não aparecem mais enquanto problema, desvantagem ou destino trágico, mas sim, enquanto espetáculo aprazível e capital cultural (Engel, 2009:13). Trata-se de uma forma modulada e, certamente, mais complexa de subjetivação que o diversity management avança. Por um lado, é um governo que integra por uma política de adensamento dos desejos e prazeres sobrepostos às identidades e aos corpos. Por outro lado, é exatamente o mesmo entusiasmo afetivo que sustenta um controle mais abrangente, circulando pelas aspirações canalizadas por "ser diferente". É um conceito peculiar de diversidade que pode ser consumida com segurança, celebrada, $e$ ainda oferece o excedente de funcionar como uma política do "feel good" (Ahmed, 2012:69). Mais explicitamente, a postura antidiscriminatória da Visibly Hot em relação a negros, gays e lésbicas consegue evocar uma emoção de vitória sobre a 
discriminação, ensombrando sua fragilidade $e$ sua descontinuidade.

\section{A venda em fluxo}

Para a gestão da Visibly Hot, os afetos são os meios que veiculam todas as sensações necessárias para tornar suas vendas lucrativas. O sonho de "ser diferente", a promessa por diversidade sexo-racial e a estilização corpo-identitária por parte dos funcionários contribuem para montar uma arquitetura afetiva que encanta seus sócios. Se partirmos da hipótese farmacopornográfica de Preciado (2008), seria até um exemplo de como a densidade de imaginações excitantes e a abrangência da tecnologização corporal já fez surgir subjetividades alteradas. Essas se refletem nos jovens vendedores da Visibly Hot: são intermediários de uma geração que cria as modelações do corpo (cabelo, tatuagem, adornos, estilo de roupa) e as identidades sexo-raciais em interação constitutiva com suas projeções midiático-afetivas. Semelhante ao que Gregori notou com os funcionários e consumidores dos sex shops (Gregori, 2012:59), eles não se encaixam no papel de vítimas de "desventuras alienadas", nem se reduzem a meros artefatos do capitalismo empresarial.

No entanto, se ponderarmos sobre a abrangência dos afetos relacionados às aspirações subjetivas $e$ sexuais que atravessam $e$ se acumulam na Visibly Hot, a questão do controle, ou seja, de como essa empresa consegue - ou não - manter seus canais afetivos criando valor, permanece substancial. Afetos são fluxos que não se deixam fixar. ${ }^{5}$ Os sonhos dos jovens funcionários sobre o "ser diferente" obedecem a mudanças contínuas tanto quanto a atração sexual flutua. Nem o "DNA" da marca é isento de mutação. Consequentemente, a Visibly Hot não pode cansar de reinventar suas próprias técnicas afetivas. Ora, as adaptações de

5 De acordo com Clough, os afetos também podem ser pensados enquanto "capacidades corporais de afetar e estar afetado" (Clough, 2007:2), ou seja, eles se encontram em um estado sempre prófugo, mas com a potência de ligar $e$ movimentar corpos, colocando-os em um estado de ânimo. 
controle se processam diretamente pelas micropráticas dos vendedores: nas interações que eles iniciam com os clientes no momento da venda de mercadoria. Orientados pelos treinamentos internos, os vendedores são convidados a desenvolver suas próprias estratégias afetivas que facilitam a venda de um par de óculos.

Como disse Carol, toda pessoa teria "várias cartas na manga". Ela pessoalmente opta pela técnica do rapport, uma abordagem que ela achou e estudou pela internet. Como sugere esse termo francês, é uma técnica que visa estabelecer uma relação com o cliente, propondo um procedimento prático por três etapas:

1. Intenção: conhecer o outro;

2. Atitude: encontrar o outro em seu modelo de mundo validando seus "mapas"- valores, crenças - realidade individual;

3. Frame: deslocar-se para a posição perceptiva do outro (Portal Educação, 2013).

Nas palavras de Carol, o rapport a ajuda a "usar o emocional da pessoa". Pela conversa inicial, ela tenta entrar na posição do cliente, "pegar a pessoa, fazer a pessoa se imaginar usando esses óculos, ou imaginar dando de presente". Dependendo da situação, acrescenta, ela também força um diálogo por informações mais familiares. Ao olhar a exposição dos modelos de óculos, ela usa frases como "ah, mais tarde eu vou sair com a minha namorada", abrindo um espaço afetivo que gera possivelmente proximidade, aliás, confiabilidade para o cliente entrar na compra.

Seu colega Fernando opina que, geralmente, as pessoas procuram elogio e uma comprovação de que são atrativos. A estratégia de venda dele reside justamente em atender a essa expectativa.

O que eu falo muito para homem, quando o óculos (sic) está bonito, naquele com cara de patrão; patrão é aquele que manda, né? Você tem cara de galã. Galã é um cara 
que seduz. Eles gostam, eles morrem de rir, eles gostam, acabam levando porque eu falei essa palavra mágica. Olha só, as pessoas são carentes. Eles gostam de se sentir bem. Eu uso muito isso. Para mulher, eu uso muito a moda. Mas, às vezes eu falo que estão chiques, têm cara de riqueza, cara de rica, perua, elas morrem de rir (Fernando, vendedor da Visibly Hot).

Parecida com a estratégia de Carol, a de Fernando se baseia na força da imaginação. No entanto, Fernando atribui lugares diferentes a homens e mulheres, mobilizando, aliás, desejos heterossexuais. Ele agrada aos clientes masculinos ao retratá-los como sedutores, de sujeitos sexualmente atrativos por sua masculinidade de "galã". Igualmente, Fernando lisonjeia as clientes femininas, animando-as a descobrir sua própria elegância feminina. Nos dois casos, o vendedor acaba mobilizando a afetividade sexual. Na verdade, os afetos estão postos em marcha por fantasias que Fernando oferece aos clientes. Notavelmente, suas alusões à beleza feminina estão vinculadas à riqueza, a uma aspiração abrangente a uma vida mais brilhante. As reações afirmativas que o vendedor relata ("elas morrem de rir") dão prova de que a subjetivação heterossexual vem sendo sustentada em conjunto com a riqueza material. Em outras palavras, Fernando usa fantasias heterossexuais que alimentam o efeito duplo da interação de venda. Essa interação não produz unicamente os pré-requisitos para uma venda bem-sucedida, mas também faz surgir, pelas figuras do "galã" e da "perua", subjetividades afetivamente normatizadas.

Diferentemente de como aparecem na psicanálise de Freud, as fantasias aqui envolvidas não se desdobram como desejos insatisfeitos. Pelo contrário, essas fantasias instigadas pela interação de venda são agentes sexuais que relacionam os sujeitos ao meio social. Elas atuam enquanto tecnologia do gênero, solicitando investimentos conflitivos para sujeitos femininos $e$ masculinos (De Lauretis, 1987:3). Seus efeitos produzem, no caso, as subjetividades sexuadas que prometem o aumento do lucro. Mas, como ainda argumenta De Lauretis, o gênero não é 
simplesmente efeito de representações lineares, mas também do seu próprio excesso que "permanece fora do discurso" (De Lauretis, 1987:3): trauma, fantasia e afetos que, potencialmente, desestabilizam qualquer representação. Nas lojas da Visibly Hot, podemos traçar os vestígios desse excesso na excitação sexual mediada pelos vendedores. Uma vez que posta em marcha, a excitação não só tem efeitos animadores, mas é igualmente geradora de frustrações.

Tiago, também vendedor da Visibly Hot, relata situações significativas. Normalmente, ele costuma trabalhar junto com sua gerente Andrea, uma jovem mulher de 22 anos. "Ela é uma menina muito bonita", comenta e ainda acrescenta a semelhança dela com a modelo da então propaganda Visibly Hot: "usa batom bem vermelho, cabelo loiro, bem sexy." Mas, essa atratividade também lhe é fatal. Tiago sempre é testemunha de que a excitação partindo dela provoca ciúmes. A situação mais comum ocorre quando se aproxima da loja um casal heterossexual. Andrea, por ativar sua própria atitude sexo-profissional, suscita uma tensão de paquera que se prende nas reações afetivamente normatizadas dos clientes. Enquanto consegue agradar ao homem, a namorada se revolta porque percebe uma concorrência sexual ameaçadora. De acordo com o relato de Tiago, dura menos de um minuto até que a namorada fique "chateada" e faça com que seu namorado vá embora da loja.

Nesse exemplo, a sedução interrompe, imprevistamente, o fluxo das vendas. O trabalho afetivo se mostra um negócio arriscado, pois não é uma atividade com resultados a serem completamente gerenciáveis. Paradoxalmente, esse trabalho coproduz os pré-requisitos da sua própria falha. Por um lado, a incitação dos desejos entre vendedor e cliente se propõe a liberar estilos de vida diferentes e aumentar o caráter - nas palavras da Visibily Hot - exótico e transgressivo da marca. Por outro lado, não há técnica nenhuma que consiga abranger os impulsos espontâneos que são imanentes aos afetos. O flerte, o batom vermelho, a raça estilizada, tudo isso sustenta um controle mais sofisticado do capital e das subjetividades, do mesmo modo que 
instiga a criatividade e a intervenção dos seus atores envolvidos. A gerente Andrea, por exemplo, costuma investir horas para tratar $e$ ajeitar seu penteado no cabeleireiro, um tempo que transborda qualquer racionalidade do seu tempo oficial de trabalho. De modo colateral, o entusiasmo por parte dos jovens vendedores de, como dizem, "poder brincar e curtir" no local do trabalho sempre mexe com o limite da desatenção que põe em perigo as vendas.

\section{Conclusão}

É o slogan da última convenção que melhor retrata a missão própria da Visibly Hot: "Não é uma questão de ter. É uma questão de ser". Sendo exemplar para as tendências contemporâneas provenientes das indústrias comerciais, assistimos a uma intensificação de técnicas afetivas que excitam os desejos identitários e sexuais. Na verdade, o caso da Visibly Hot ilustra que as promessas por subjetividades "diferentes" estão arquitetando uma composição de instrumentos poderosos, possibilitando-lhe a realização de formas espontâneas de controle (de si e dos outros) que, ao mesmo tempo, garantem seu sucesso econômico. A esse respeito, a participação ativa dos funcionários $e ́$ crucial. Altamente motivados para identificar-se, afetiva $e$ corporalmente, com a marca ("eu amo a marca", "aqui posso ser quem sou", "eles vão me aceitar com a minha opção sexual"), os funcionários alimentam a própria vivacidade dos conceitos empresariais. Por um lado, sua estilização corporal torna efetiva a chamada gestão da diversidade (diversity management). Por outro lado, o trabalho afetivo que os vendedores realizam diariamente pela interação com os clientes põe em marcha sua produtividade ambígua. Por ativar fantasias sexuais ou técnicas sociais para animar os clientes, eles criam um ambiente informal e efetivo para as vendas. Porém, a estimulação de afetos também produz sujeitos e sentimentos contraprodutivos: ciúmes sexuais $e$ atitudes excessivas que interrompem os processos voltados para a venda. 


\section{Referências bibliográficas}

ADKINS, Lisa. Gendered Work: Sexuality, Family and the Labour Market. Bristol PA, Open University Press, 1995.

AHMED, Sara. Collective Feelings: Or, the Impressions Left by Others. Theory, Culture \& Society (21), London/Thousand Oaks/New Delhi, 2004, pp.25-42.

. On Being Included. Racism and Diversity in Institutional Life. London/Durham, Duke University Press, 2012.

BRAH, Avtar. Diferença, diversidade, diferenciação. Cadernos Pagu (26), Campinas-SP, Núcleo de Estudos de Gênero-Pagu/Unicamp, 2006, pp.329-376.

BRITES, Jurema. Afeto e desigualdade: gênero, geração e classe entre empregadas domésticas e seus empregadores. Cadernos Pagu (29), Campinas-SP, Núcleo de Estudos de Gênero-Pagu/Unicamp, 2007, pp.91-109.

Clough, Patricia Ticineto (Ed.). The Affective Turn. Theorizing the Social. Durham/London, Duke University Press, 2007.

DE LAURETIS, Teresa. Technologies of Gender. Essays on Theory, Film, and Ficition. Bloomington and Indianapolis, Indiana University Press, 1987.

ENGEL, Antke. Bilder von Sexualität und Ökonomie. Queere kulturelle Politiken im Neoliberalismus. Bielefeld, Transcript, 2009.

FACCHINI, Regina. "Não faz mal pensar que não se está só": estilo, produção cultural e feminismo entre as minas do rock em São Paulo. Cadernos Pagu (36), Campinas-SP, Núcleo de Estudos de GêneroPagu/Unicamp, 2011, pp.117-153.

FRANÇA, Isadora Lins. Consumindo lugares, consumindo nos lugares: homossexualidade, consumo e subjetividade na cidade de São Paulo. Tese de doutorado, Ciências Sociais, Unicamp, 2010.

GREGORI, Maria Filomena. Erotismo, mercado e gênero. Uma etnografia dos sex shops de São Paulo. Cadernos Pagu (38), Campinas-SP, Núcleo de Estudos de Gênero-Pagu/Unicamp, 2012, pp.53-97. 
HALL, Stuart. Introduction: Who Needs 'Identity'? In: HALL, Stuart; DU GAY, Paul (orgs.). Questions of Cultural Identity. London/Thousand Oaks/New Delhi, SAGE, 1996, pp.1-17.

HARDT, Michael; Negri, Antonio. Império. Rio de Janeiro, Record, 2006.

HiRATA, Helena; GuimARÃES, Nadya Araújo (Eds.). Cuidado e cuidadoras: as várias faces do trabalho do care. São Paulo, Atlas, 2012.

HochSCHILD, Arlie Russell. The Managed Heart. Commercialization of Human Feeling. Berkeley CA, University of California Press, 2003 [1984].

ISAACSON, Walter. Steve Jobs. A biografia. Rio de Janeiro, Companhia das Letras, 2011.

LORENZ, Renate; KUSTER, Brigitta. sexuell arbeiten - eine queere perspektive auf arbeit und prekäres leben. Berlin, b_books, 2007.

MaSsumi, Brian. Parables for the Virtual: Movement, Affect, Sensation. Durham, NC, Duke University Press, 2002.

MCCLINTOCK, Anne. Couro Imperial. Raça, gênero e sexualidade no embate colonial. Campinas, Editora Unicamp, 2010.

MCROBBIE, Angela. Reflections on Feminism and Immaterial labour. New Formations (70), London, Goldsmiths Research Online, 2010, pp.6076.

MoUTINHO, Laura. Negociando com a adversidade: reflexões sobre "raça", (homos)sexualidade e desigualdade social no Rio de Janeiro. Revista Estudos Feministas (14), Florianópolis, 2006, pp.103-116.

PisCiTElli, Adriana. Corporalidade em confronto. Revista Brasileira de Ciências Sociais (22), 2007, pp.17-32.

. As fronteiras da transgressão: a demanda por brasileiras na indústria do sexo na Espanha. Sexualidad, Salud y Sociedad - Revista Latinoamericana (1), CLAM-UERJ, Rio de Janeiro, 2009, pp.177201.

PORTAL Educação. Técnicas de rapport. Artigos Administração e Gestão. 14 de fevereiro, 2013 [http://www.portaleducacao.com.br/educacao/artigos/ 33461/tecnicasde-rapport - acesso em: 29 jun 2014]. 
PreCIADO, Beatriz. Testo Yonqui. Madrid, Espasa, 2008.

SARAIVA, Luiz Alex; IRIGARAY, Hélio Arthur. Políticas de diversidade nas organizações: uma questão de discurso? Revista de Administração de Empresas (49), São Paulo, 2009, pp.337-348.

SCHMITZ, Sigrid; AHMED, Sara. Affect/Emotion: Orientation Matters. Freiburger Zeitschrift für GeschlechterStudien (20), Freiburg, 2014, pp.97-108.

SOARES, Angelo. Les émotionsdans le travail. Revue internationale de psychopathologie et de psychodynamique du travail (9), Paris, 2002, pp.9-18.

SHAMOON, Sumaira; TEHSEEN Saiqa. Brand Management: What Next? Interdisciplinary Journal Of Contemporary Research In Business 2 (12), Canterbury and Western Cape, 2011, pp.435-441.

VARGAS, Sonia Regina. Transformações da subjetividade no exercício do trabalho imaterial. Estudos e Pesquisas em Psicologia (2), Rio de Janeiro, UERJ, 2009, pp.512-524. 